\author{
Media Publikasi Promosi Kesehatan Indonesia \\ The Indonesian Journal of Health Promotion
}

\title{
Analisis Faktor Kelengkapan Imunisasi Dasar Pada Balita Di Wilayah Kerja Puskesmas Cempaka Banjarmasin
}

\author{
The analysis factor of basic immunization completeness on toddlers at working area of \\ cempaka health center Banjarmasin
}

\author{
${ }^{(1 *)}$ Yeni Riza, ${ }^{(2)}$ Norfai, ${ }^{(3)}$ Mirnawati \\ ${ }_{(1,2,3)}$ Fakultas Kesehatan Masyarakat UNISKA \\ ${ }^{\left({ }^{*}\right)}$ yeniriza86@gmail.com, ${ }^{(2)}$ norfai92@gamil.com, ${ }^{(3)}$ mirnabjm@gmail.com,
}

\begin{abstract}
Abstrak
Imunisasi merupakan salah satu bentuk intervensi kesehatan yang sangat efektif dalam upaya menurunkan angka kematian bayi dan balita. Puskesmas Cempaka Banjarmasin dari tahun 2015-2017 mengalami peningkatan pencapaian setiap tahunnya walaupun dengan persentase yang tidak terlalu signifikan pada tahun 2015 sebesar 89,7\%, 2016 sebesar 96,1\%, 2017 sebesar 102,9\%. Penelitian ini bertujuan untuk mengetahui dan menganalisis hubungan pengetahuan, tingkat pendidikan, dan dukungan suami dengan kelengkapan imunisasi dasar pada balita di wilayah kerja Puskesmas Cempaka Banjarmasin tahun 2018. Penelitian ini menggunakan survei analitik dengan pendekatan cross sectional. Besar sampel yang di dapatkan sebanyak 54 responden dengan cara pengambilan sampel menggunakan accidental sampling. Instrument penelitian yang digunakan yaitu, kuesioner dan wawancara secara langsung kepada responden yang berkunjung ke Puskesmas Cempaka Banjarmasin. Analisis data menggunakan uji statistik Chi square dengan tingkat kepercayaan 95\%. Berdasarkan hasil uji statistik menunjukkan bahwa terdapat hubungan yang bermakna antara pengetahuan dengan kelengkapan imunisasi dasar pada balita di wilayah kerja Puskesmas Cempaka Banjarmasin tahun 2018 dengan (nilai $\mathrm{p}$ value $=0,000<\alpha 0,05$ ) dan terdapat hubungan yang bermakna antara dukungan suami dengan kelengkapan imunisasi dasar pada balita di wilayah kerja Puskesmas Cempaka Banjarmasin tahun 2018 dengan (nilai $\mathrm{p}$ value $=0,000<\alpha 0,05)$, sedangkan variabel yang tidak berhubungan dengan kelengkapan imunisasi dasar pada balita adalah tingkat pendidikan dengan (nilai $\mathrm{p}$ value $=1,000>\alpha 0,05$ ). Perlunya peningkatan frekuensi penyuluhan oleh petugas kesehatan kepada kader posyandu ataupun masyarakat langsung tentang manfaat imunisasi dasar, dampak jika anak tidak mendapatkan imunisasi dasar dan tujuan pemberian imunisasi dasar.
\end{abstract}

Kata Kunci : Dukungan Suami; Imunisasi; Pengetahuan; Pendidikan

\begin{abstract}
Immunization is one form of health intervention that is very effectice in the effort of decreasing death rate of babies and toddlers. Cempaka Health Center Banjarmasin since 2015-2017 has had the inreasing of accomplishment in each year although with thepercentation thatwas not too significant in 2015 that was 89,7\%, 2016 was 96,1\%, 2017 was 102,9\%. The research was aimed to know and analyze the relation between knowledge, education level, and husband's support with the basic immunization completeness on toddlers at working area of Cempaka Health Center Banjarmasin year 2018. The research used analytic surveywith cross sectional approach. The number of sample was 54 by using accidental sampling. Instrumentused in the research was questionnaire that was given to respondents who visited Cempaka Health Center Banjarmasin. Data analysis used Chi Square statistic test with the credibility level was 95\%. Based on the result of the statistic test showed that there was significant relation between knowledge and basic immunization completeness on toddlers at working area of Cempaka Health Center Banjarmasin year 2018 with ( $p$ value $=0,000<\alpha 0$,05) and there was significant relation between husband's support and basic immunization completeness on toddlers at working area of Cempaka Health Center Banjarmasin year 2018 with(p value = $0,000<\alpha 0,05)$, meamwhile the variable that was not related to basic immunization completeness on toddlers was education level with ( $p$ value $=1,000>\alpha 0,05)$. The increasing of counselling frequention by health workers is neededto cadres or public directly about the benefits of basic immunization, the impact if children don't get basic immunization, and the aim of giving basic immunization.
\end{abstract}

Keywords: Husband's Support; Immunization; Knowledge; Education 


\section{PENDAHULUAN}

Untuk mewujudkan derajat kesehatan masyarakat yang setinggi - tingginya diperlukan upaya untuk mencegah terjadinya suatu penyakit melalui imunisasi, bahwa untuk melaksanakannya perlu mengatur ketentuan mengenai penyelenggaraan imunisasi. Imunisasi adalah suatu upaya untuk menimbulkan / meningkatkan kekebalan seseorang secara aktif terhadap suatu penyakit sehingga bila suatu saat terpajan dengan penyakit tersebut tidak akan sakit atau hanya mengalami sakit ringan (1). Imunisasi dasar yang diwajibkan pada bayi usia 0-9 bulan yaitu BCG, Campak, DPT, Hepatitis B, dan Polio. Imunisasi dasar berfungsi memberikan perlindungan dan penurunan resiko morbiditas dan mortalitas terhadap penyakit yang dapat dicegah dengan imunisasi (2).

Profil Kesehatan Indonesia Tahun 2014 menunjukkan 2 jumlah penyakit tetanus neonatorum sebesar 64,3\% meningkat dari tahun sebelumnya yang sebesar 53,8\% dengan jumlah meninggal 54 kasus. Penyakit campak terdapat pada 12.943 kasus meningkat dari tahun 2013 sebesar 11.521 kasus dan difteri sebanyak 396 kasus dengan jumlah kasus meninggal sebanyak 16 kasus (3).

Hasil cakupan imunisasi secara nasional terus alami peningkatan. Berdasarkan Evaluasi Program Imunisasi selama 2015-2016, cakupan imunisasi dasar lengkap pada bayi mencapai 86,5\% pada 2015 dengan target yang ditetapkan untuk tahun itu yaitu 91\% dan 91,1\% pada 2016 dengan target yang harus dicapai adalah 91,5\%. (6) Di Kalimantan Selatan pada tahun 2017 cakupan imunisasi dasar lengkap telah mencapai 81,5\% dengan jenis vaksin dan imunisasi BCG sebesar 81,3\%, Hb0 sebesar 82,0\%, DPT/Hb 1 sebesar 84,8\%, DPT/Hb 3 sebesar 80,8\%, Polio 4 sebesar 80,3\%, Campak sebesar $81,8 \%$.

Berdasarkan data yang didapat dari Puskesmas Cempaka yaitu, persentase cakupan imunisasi dasar lengkap dari tahun 2015-2017 mengalami peningkatan pencapaian setiap tahunnya dengan persentase pada tahun 2015 sebesar 89,7\%; tahun 2016 sebesar 96,1\%; dan pada tahun 2017 sebesar 102,9\% dengan pencapaian nasional pada tahun 2017 sebesar 92\% yang artinya Puskesmas Cempaka Banjarmasin melebihi target pencapaian nasional.

Tujuan peniltian ini untuk mengetahui dan menganalisis hubungan pengetahuan, tingkat pendidikan, dan dukungan suami dengan kelengkapan imunisasi dasar pada balita di wilayah kerja Puskesmas Cempaka Banjarmasin tahun 2018.

\section{METODE}

Penelitian ini menggunakan desain penelitian survei analitik dengan pendekatan cross sectional. Penelitiaan ini dilakukan pada ibu balita yang berada di wilayah kerja puskesmas cempaka Banjarmasin. Populasi penelitian ini adalah semua ibu yang memiliki balita berusia 1-5 tahun yang berada di wilayah kerja Puskesmas Cempaka Banjarmasin. Cara pengambilan sampel dengan menggunakan Accidental Sampling dengan besar sampel 54 orang. Instrumen yang digunakan dalam penelitian ini adalah kuesioner dan wawancara secara langsung dengan pengolahan data secara editing, coding, entry data. Analisis data yang dilakukan adalah univariat dan bivariat dengan uji statistic chi squere menggunakan aplikasi SPSS.

\section{HASIL}

Tabel 1 (lampiran) menggambarkan kararakteristik subjek penelitian, berdasarkan tabel diketahui bahwa dari jumlah responden sebanyak 54 orang didapatkan sebanyak 46 responden $(85,2 \%)$ dengan status imunisasi lengkap dan sebanyak 8 responden (49,5\%) dengan status imunisasi tidak lengkap. Dari hasil tersebut juga dapat diketahui bahwa tingkat pengetahuan responden dengan kategori baik sebanyak 35 responden $(64,8 \%)$, pengetahuan cukup 
sebanyak 13 responden (24,1\%), dan pengetahuan kurang sebanyak 6 responden (11,1\%). Berdasarkan tabel 1 menunjukan bahwa sebagian besar responden di wilayah kerja Puskesmas Cempaka Banjarmasin memiliki tingkat pendidikan menengah sebanyak 22 responden (40,7\%), pendidikan rendah sebanyak 19 responden (35,2\%), dan pendidikan tinggi sebanyak 13 responden $(24,1 \%)$ hasil penelitian juga menunjukan bahwa sebagian besar responden di wilayah kerja Puskesmas Cempaka Banjarmasin mendapat dukungan suami sebanyak 44 responden (81,5\%), tidak mendapat dukungan suami sebanyak 10 responden $(18,5 \%)$.

Tabel 2 (lampiran) menunjukan bahwa dari 35 responden yang memiliki pengetahuan baik dengan imunisasi lengkap sebanyak 32 responden $(91,4 \%)$ dan pengetahuan baik dengan imunisasi tidak lengkap sebanyak 3 responden $(8,6 \%)$, sedangkan 13 responden yang memiliki pengetahuan cukup imunisasi lengkap 13 responden $(100 \%)$ dan 0 responden pengetahuan cukup imunisasi tidak lengkap $(0,0 \%)$, sedangkan 6 responden yang pengetahuan kurang imunisasi lengkap 1 responden (16,7\%), dan pengetahuan kurang tidak lengkap imunisasi sebanyak 5 responden $(83,3 \%)$. Dari hasil uji statistik diperoleh nilai $\mathrm{p}=0,000(\mathrm{p}<0,05)$. Hal ini menunjukan bahwa ada hubungan antara pengetahuan dengan kelengkapan imunisasi dasar pada balita di Puskesmas Cempaka Banjarmasin.

Tabel 3 (lampiran) menunjukan bahwa dari 22 responden yang memiliki tingkat pendidikan menengah dengan imunisasi lengkap sebanyak 9 responden $(69,2 \%)$ dan pendidikan menengah dengan imunisasi tidak lengkap sebanyak 1 responden (4,5\%), sedangkan 19 responden yang memiliki pendidikan rendah dengan imunisasi lengkap 16 responden $(84,2 \%)$ dan 3 responden pendidikan rendah dengan imunisasi tidak lengkap $(15,8 \%)$, sedangkan 13 responden yang pendidikan tinggi dengan imunisasi lengkap 9 responden $(69,2 \%)$, dan pendidikan tinggi dengan tidak lengkap imunisasi sebanyak 4 responden (30,8\%). Dari hasil uji statistik diperoleh nilai $p=1,000(p>0,05)$. Hal ini menunjukan bahwa tidak ada hubungan antara tingkat pendidikan dengan kelengkapan imunisasi dasar pada balita di Puskesmas Cempaka Banjarmasin.

Tabel 4 (lampiran) menunjukan bahwa dari 44 responden dari variabel dukungan suami yang mendukung dengan status imunisasi lengkap sebanyak 42 responden (95,5\%) dan mendukung dengan status imunisasi tidak lengkap sebanyak 2 responden (4,5\%), sedangkan 10 responden dari variabel dukungan suami yang tidak mendukung dengan status imunisasi lengkap 4 responden (40,4\%) dan 6 responden tidak mendukung dengan status imunisasi tidak lengkap (60,6\%). Dari hasil uji statistik diperoleh nilai $p=0,000(p>0,05)$. Hal ini menunjukan bahwa ada hubungan antara dukungan suami dengan kelengkapan imunisasi dasar pada balita di Puskesmas Cempaka Banjarmasin.

\section{PEMBAHASAN}

Pengetahuan merupakan hasil dari tahu dan ini terjadi setelah orang melakukan pengindraan terhadap suatu objek tertentu. Pengindraan terjadi melalui panca indera manusia yakni indera penglihatan, pendengaran, penciuman, rasa dan raba. Pengetahuan merupakan domain yang sangat penting dalam membentuk tindakan seseorang (4). Dalam hal ini peran orang tua, khususnya ibu menjadi sangat penting, karena orang terdekat dengan bayi dan anak adalah ibu. Demikian juga dengan pengetahuan ibu. Pengetahuan ibu akan mempengaruhi kelengkapan imunisasi dasar pada bayi dan anak, sehingga dapat mempengaruhi status imunisasinya (5).

Hal ini sejalan dengan hasil penelitian Elly Istriyati (2011) bahwa dalam penelitiannya mengatakan ada hubungan antara pengetahuan responden dengan kelengkapan imunisasi dasar pada balita (6). Hasil penelitian ini juga sejalan dengan teori dalam Notoatmodjo (2007), menyatakan bahwa terdapat kecenderungan seseorang yang berpengetahuan tinggi akan cenderung mempunyai perilaku yang baik dalam bidang kesehatan dalam hal ini untuk 
mengimunisasikan anaknya (7).

Dalam penelitian ini penulis mendapatkan hasil tidak ada hubungan antara tingkat pendidikan dengan kelengkapan imunisasi dasar di wilayah kerja Puskesmas Cempaka Banjarmasin. Hasil penelitian ini tidak sejalan dengan hasil penelitian Elly Istriyati (2011) bahwa dalam penelitiannya mengatakan ada hubungan antara tingkat pendidikan dengan kelengkapan imunisasi dasar pada balita di Desa Kumpulrejo Kecamatan Argomulyo Kota Salatiga (6). Akan tetapi penelitian saya sejalan dengan Desti Diana Sari (2018) bahwa dalam penelitiannya mengatakan tidak ada hubungan antara tingkat pendidikan dengan kelengkapan imunisasi dasar pada balita (8).

Dari data dapat diketahui bahwa tingkat pendidikan tidak menjamin seseorang atau balita mendapatkan imunisasi dasar lengkap, banyak faktor yang mempengaruhi pemberian imunisasi dasar pada balita ini seperti hal nya ketakutan orang tua ketika anaknya sakit setelah di imunisasi, faktor kebudayaan yang juga sedikit berpengaruh terhadap pemberian imunisasi dasar dan banyak faktor lainnya.Jika diteliti lagi mengapa tingkat pendidikan tidak berpengaruh dengan kelengkapan imunisasi, ini berkaitan juga dengan tingkat pengetahuan ibu di karenakan banyak nya promosi kesehatan tentang imunisasi yang dilakukan puskesmas dan juga kader posyandu dalam menurunkan angka kematian bayi / balita.

Seorang ibu yang memiliki sikap positif terhadap imunisasi anaknya perlu mendapat dukungan dari suami berupa konfirmasi atau izin dan fasilitas yang mempermudah jangkauan imunisasi serta motivasi untuk rutin imunisasi sesuai jadwal. Hasil penelitian ini sejalan dengan teori yang dikemukan oleh Sujiyanto (2010) dukungan suami merupakan dorongan terhadap ibu baik secara moral maupun material, dimana dukungan suami sangat mempengaruhi ibu dalam hal apapun termasuk dalam pemberian imunisasi (9). Hal ini sejalan dengan hasil penelitian Hermiati (2014) bahwa dalam penelitiannya mengatakan ada hubungan antara dukungan suami dengan kelengkapan imunisasi dasar pada balita (10).

Hasil penelitian ini juga diperkuat oleh teori Cobb (2010) yang menyatakan tingkat penerimaan imunisasi dipengaruhi oleh faktor dorongan suami, jika suami memberikan persetujuan maka tingkat penerimaan akan lebih cepat, begitu juga sebaliknya. Peranan suami dalam imunisasi yaitu menganjurkan, mendukung serta memberikan izin pada istri untuk memberikan imunisasi dasar lengkap pada bayi guna untuk mencegah penyakit seperti polio, campak, batuk rejan, tetanus dan hepatitis (11).

\section{KESIMPULAN DAN SARAN}

Kelengkapan imunisasi dasar pada balita di wilayah kerja di Puskesmas Cempaka Banjarmasin tahun 2018 adalah paling banyak dengan status imunisasi lengkap sebesar $(85,2 \%)$ dengan pengetahuan responden tentang imunisasi paling banyak pengetahuan baik yaitu $(64,8 \%)$ dan mendapat dukungan suami sebanyak $(81,5 \%)$ dengan tingkat pendidikan menengah sebesar (40,7\%) di wilayah kerja Puskesmas Cempaka Banjarmasin tahun 2018.

Hasil tersebut menunjukan bahwa ada hubungan yang bermakna antara pengetahuan dan dukungan suami dengan kelengkapan imunisasi dasar pada balita di wilayah kerja Puskesmas Cempaka Banjarmasin. Akan tetapi berbeda dengan tingkat pendidikan yang menyatakan tidak ada hubungan dengan kelengkapan imunisasi dasar pada balita di wilayah kerja Puskesmas Cempaka Banjarmasin tahun 2018.

Perlunya peningkatan frekuensi penyuluhan oleh petugas kesehatan kepada kader posyandu ataupun masyarakat langsung tentang manfaat imunisasi dasar, dampak jika anak tidak mendapatkan imunisasi dasar dan tujuan pemberian imunisasi dasar. 


\section{DAFTAR PUSTAKA}

1. Kemenkes, 2017. Profil Kesehatan Indonesia 2016. Jakarta : Permenkes RI

2. Mulyani, N.S. (2013). Imunisasi untuk anak. Yogyakarta : Nuha Medik

3. Kemenkes RI, 2014. Profil kesehatan Indonesia 2014. Jakarta : Kemenkes RI 2015. Menkes RI. 2014. Peratutan Menteri Kesehatan Nomor 1059/Menkes/SK/IX/2004 Tentang Pedoman Penyelenggaraan Imunisasi. Jakarta : Permenkes RI.

4. Notoatmodjo, S, 2012. Metodelogipenelitiankesehatan.Jakarta:RinekaCipta.

5. Arsunan. 2006. Ilmu Kesehatan Masyarakat. Jakarta : Rineka Cipta

6. Istriyati, E, 2011. Faktor - faktor yang berhubungan dengan pemberian kelengkapan imunisasi dasar bayi di desa kumpul rejo kecamatan argomulyo kota salatiga. [skripsi]. Fakultas Ilmu Keolahragaan : Universitas Negeri Semarang. [online]. http://lib.unnes.ac.id/570/1/7055.pdf [diakses 02 Mei 2018]

7. Notoatmodjo, S., 2007. Promosi Kesehatan dan Ilmu Perilaku. Jakarta : Rineka Cipta.

8. Sari, D.D, 2018. Faktor - faktor Pada Ibu Yang Berhubungan Dengan Pemberian imunisasi Dasar Bayi Di Wilayah Kerja Puskesmas Korpri Kecamatan Sukarame Kota Bandar lampung. [skripsi]. Fakultas Ilmu Kedokteran : Universitas Lampung. [online]. http://lib.unnes.ac.id/570/1/7055.pdf [diakses 02 Mei 2018]

9. Sujiyanto, 2011. Pengertian Dukungan. [online]. http://dukungan-suami keluarga.blogspot.com/2011/01/makalah -balita.html [diakses 05 Agustus 2018

10. Hermiati, 2011. Hubungan Dukungan suami Dan Pengetahuan Ibu Bayi Dengan Pemberian Imunisasi Dasar Di Desa Jegedayu Kecamatan Jagong Jeged Kabupaten Aceh Tengah. [skripsi]. Fakultas Ilmu Kesehatan : Universitas U'Budiyah Banda Aceh. [online]. http://simtakp.uui.ac.id/docjurnal/HERMIATI-jurnal_hermiati.pdf [diakses 05 Agustus2018]

11. Cobb, 2010. Teori Dukungan Suami. [online]. http://teori.com.Html. [diakses 05 Agustus 2018]

\section{LAMPIRAN}

Tabel 1.

Distribusi Frekuensi Variabel Penelitian

\begin{tabular}{ccc}
\hline Variabel & N & \% \\
\hline Kelengkapan Imunisasi Dasar & 46 & 85,2 \\
Lengkap & 8 & 14,8 \\
Tidak Lengkap & & \\
Pengetahuan & 35 & 64,8 \\
Baik & 13 & 24,1 \\
Cukup & 6 & 11,1 \\
Kurang & 13 & 24,1 \\
Tingkat Pendidikan & 22 & 40,7 \\
Tinggi & 19 & 35,2 \\
Menengah & & 81,5 \\
Rendah & 44 & 18,5 \\
Dukungan Suami & 10 & $\mathbf{1 0 0}$ \\
Mendukung & $\mathbf{5 4}$ & \\
Tidak Mendukung & & \\
Total & &
\end{tabular}


Tabel 2.

Hubungan Antara Pengetahuan Dengan Kelengkapan Imunisasi Dasar Pada Balita

\begin{tabular}{|c|c|c|c|c|c|c|c|}
\hline \multirow[t]{3}{*}{ Pengetahuan } & \multicolumn{4}{|c|}{ Kelengkapan Imunisasi Dasar } & \multirow{2}{*}{\multicolumn{2}{|c|}{ Total }} & \multirow{3}{*}{$\mathrm{p}$ value } \\
\hline & \multicolumn{2}{|c|}{ Lengkap } & \multicolumn{2}{|c|}{ Tidak Lengkap } & & & \\
\hline & $\mathrm{n}$ & $\%$ & $\mathrm{n}$ & $\%$ & $\mathrm{~N}$ & $\%$ & \\
\hline$\overline{\text { Baik }}$ & 32 & 91,4 & 3 & 8,6 & 35 & 100 & \\
\hline Cukup & 13 & 100,0 & 0 & 0,0 & 13 & 100 & 0,000 \\
\hline Kurang & 1 & 16,7 & 5 & 83,3 & 6 & 100 & \\
\hline Jumlah & 46 & 85,2 & 8 & 14,8 & 54 & 100 & \\
\hline
\end{tabular}

Tabel 3.

Hubungan Antara Tingkat Pendidikan Dengan Kelengkapan Imunisasi Dasar Pada Balita

\begin{tabular}{|c|c|c|c|c|c|c|c|}
\hline \multirow[t]{3}{*}{ Tingkat Pendidikan } & \multicolumn{4}{|c|}{ Kelengkapan Imunisasi Dasar } & \multirow{2}{*}{\multicolumn{2}{|c|}{ Total }} & \multirow{3}{*}{$\mathrm{p}$ value } \\
\hline & \multicolumn{2}{|c|}{ Lengkap } & \multicolumn{2}{|c|}{ Tidak Lengkap } & & & \\
\hline & $\mathrm{n}$ & $\%$ & $\mathrm{n}$ & $\%$ & $\mathrm{~N}$ & $\%$ & \\
\hline Tinggi & 9 & 69,2 & 4 & 30,8 & 13 & 100 & \\
\hline Menengah & 21 & 95,5 & 1 & 4,5 & 22 & 100 & 1,000 \\
\hline Rendah & 16 & 84,2 & 3 & 15,8 & 19 & 100 & \\
\hline Jumlah & 46 & 85,2 & 8 & 14,8 & 54 & 100 & \\
\hline
\end{tabular}

Tabel 4.

Hubungan Antara Dukungan Suami Dengan Kelengkapan Imunisasi Dasar Pada Balita

\begin{tabular}{|c|c|c|c|c|c|c|c|}
\hline \multirow[t]{3}{*}{ Dukungan Suami } & \multicolumn{4}{|c|}{ Kelengkapan Imunisasi Dasar } & \multirow{2}{*}{\multicolumn{2}{|c|}{ Total }} & \multirow{3}{*}{$\mathrm{p}$ value } \\
\hline & \multicolumn{2}{|c|}{ Lengkap } & \multicolumn{2}{|c|}{ Tidak Lengkap } & & & \\
\hline & $\mathrm{n}$ & $\%$ & $\mathrm{n}$ & $\%$ & $\mathrm{~N}$ & $\%$ & \\
\hline Mendukung & 42 & 95,5 & 2 & 4,5 & 44 & 100 & \multirow{3}{*}{0,000} \\
\hline Tidak Mendukung & 6 & 40,4 & 6 & 60,6 & 10 & 100 & \\
\hline Jumlah & 46 & 85,2 & 8 & 14,8 & 54 & 100 & \\
\hline
\end{tabular}

